the neck; the texture of the brain is, I think, generally darker, and the white part more strongly fibrous; but I speak from extremely limited experience." Speaking of the Hindús, he states (' Races of Men,' p. 246), that two young Brahmins which he saw had "heads peculiarly formed -hammer-shaped, in fact-set on the neck differently from the European."

It is to be hoped that the forthcoming detailed examination, by $\mathrm{Dr}$. Knox and Mr. Carter Blake, of a large series of recent skulls in the Ethnological Society's collection, may lead to some satisfactory result on this interesting question.-I am, etc.,

\title{
Polygenist.
}

\section{Flint Implements.}

Sir,- One or two statements made in an article which appeared in the 'Geologist' of last month, on M. Gras' attack on the evidence of the Flint Implements in respect to the antiquity of man, seem to me to require correction.

In touching upon one of the points of M. Gras' attack, viz. "the astonishing multitude of these axes," the following interrogative is put and answered :- "But, in reality, how common are the true worked flints? We have seen one only from all the great gravel-beds round and under London; and miles of them have lately been cut through for the sewerworks. We have seen, may be, half-a-dozen from Suffolk, a like number from Bedford, two or three from Kent, and less than a dozen from all parts of England. As to the Yorkshire specimens, we must know more about them, and where they come from, before we can say much about them. I suppose, however, whether ancient or modern, not more than a hundred exist from that, the largest county in England, and numbering as many acres as there are words in the Bible."

From the above extract it appears that considerable doubt exists as to the genuineness of the numerous collections of flint-implements made by various individuals in the last-named county. About twenty years ago, I casually saw at Boynton Hall, which is situate a few miles from Bridling. ton, and which belongs to Sir George Strickland, a small but interesting collection of flint arrowheads, axes, etc., made previous to the year 1800 . It was after my inspection of this collection that $I$ was induced to search in the same localities; and during the period above-mentioned, I have accumulated several thousands; nine-tenths I have picked up myself, and the rest have been brought to me by men and children who have found them while working in the fields. I beg to refer your readers to a lecture delivered by the Rev. T. Wiltshire to the Geologists' Association at the beginning of the year, on the "Ancient Flint Implements of Yorkshire, and the Modern Fabrication of similar Specimens." On this occasion the reverend gentleman exhibited two hundred and sixty-eight specimens. To show, however, with what facility spurious flint weapons could be manufactured, a person was in attendance who, with only a small piece of iron rod, bent at the end, produced by a little dexterous manipulation almost any shape required. The forged implements, however, may be detected by the practised eye, as there are certain peculiarities about them which make them differ from the authentic ones. Those interested in such matters I would refer to a report of my collection, which appeared in the third volume of the Proceedings of the Leeds and West Riding of York- 
shire Philosophical Society; and also to 'The Celt, the Roman, and the Saxon,' by T. Wright, Fisq.

At the conclusion of the article alluded to, the following question is asked: "Will M. Gras assert he has ever seen a pointed weapon either ground or polished?" As this question is put to M. Gras under the impression that there are no such pointed tools or weapons, I may state there are such in my collection, though I confess they are by no means common, for, during the whole period that I have devoted to collecting these things, I have found but three.

The majority of my rudest weapons and tools were found at greater depths, generally speaking, than those which are more elaborately worked, and the transition in Yorkshire from the rude to the more highly finished implements may be said to have been gradual and apparently uninterrupted; for we find on the same land at various depths, first the most artistic, then a little lower others ruder in shape, and a few inches above the Chalk they are found amongst gravel through which water highly charged with oxide of iron has percolated, thereby changing the colour of the flints there embedded, which are generally very rude in their make. Many of the arrowheads and spear-points exhibit quite a porcellaneous appearance, which betokens their great antiquity. Those discovered in sandy places are of the natural colour, but are very bright on the surface.

There can be little doubt that flint-implements were used up to a comparatively late date.* If in Yorkshire-weapons and tools to be coated with carbonate of lime and stained with oxide of iron, and also ground at the point, be an indication of their antiquity, then the Yorkshire flints are as old as any hitherto found. And why should it not be so ? " seeing that we find ordinary gravel-flints in myriads on the surface of the soil. Can you go through any field, over any downs, across any chalk country, and not pick up, if you please, tons apon tons or cartload upon cartload? If one sort, why not then another? Is the proportion of flint-implements to unworked stones likely to be less in the disintegrated gravel-bed strewn over the soil than in the solid untouched stratum lying intact in the earth? And if not, are we less likely to find flint-implements on the surface of the soil than in the gravel-beds beneath it? We are sure we need not reply to these questions : our readers will have answered for themselves."

\section{Bridlington, Yorkshire.}

Yours, etc.,

Epw. Tindate.

[The article on M. Gras was written by me, and why my name did not appear was quite a matter of accident. All the world knows that I never hesitate to speak out; but all the world knows that if I do say a thing not exactly kind I have good grounds-or at least sincerely believe I have -before I say it. I have said I am satisfied some of the so-termed "haches reputed to be from St. Acheul" may be "haches" from St. Acheul, but are not fossil "baches" at all. They are rank forgeries. With respect

* It was the constant policy of the Romans to draught off the rising population of the conquered provinces, and send them to occupy stations, and, in fact, to form colonies in other countries. We find mentioned in old writers and in inseriptions numerous alce and cohorts of Britons in various parts of the Roman empire. According to the 'Notitia,' the fourth ala of Britons was stationed in Egypt. The twenty-sixth cohort of Britons occurs in Armenia. A body of the "Invincible Younger Britons" were stationed in Spain ; and one of the "Elder Britons" in Illyricum. The "Younger British Slingers" (funditores) are found among Palatine auxiliaries. See Wright's 'Celt, Roman, and Saxon,' foot-note, p. 104. See the above-mentioned 'Notitia,' book iv. chap. s. pp. 199, 200, etc. 
to the Yorkshire so-termed fossil specimens, I do admit that I am not a believer in them. I have seen so many deliberate forgeries from thence that I did not require the practical performance before my eyes of a Yorkshire flint-chipper to satisfy me how able some of the natives of that county were to "come Yorkshire over" us natives here. Our readers are referred to Mr. Wiltshire's paper, which we have read long ago,-but what is there in it that has anything to with the question of the fossil flint-implements of Yorkshire? Mr. Wiltshire takes up an historical topic, and deals with flint-implements from graves and entrenchments at fimber,-entrenchments, the origin of which he attributes to the Brigantes. These Fimber weapons are flint flakes, arrow-heads, and sling-stones : none of the first more than two inches long, and none of the latter more than about an inch. All this is very far away from the subject of gravel-drift: implements.

Reference is made jn our correspondent's letter

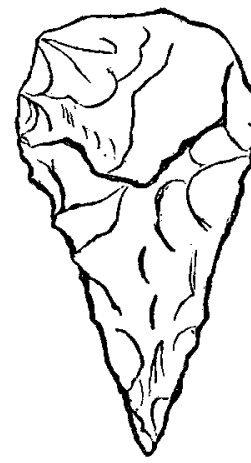

Large pointed implement ( $\frac{1}{4}$ nat. size). to the exhibition of 268 specimens of, I presume the writer means our readers to infer real fossil implements, by Mr. Wiltshire, on the reading of his paper before the Geologists' Association. Now does Mr. Tindall really mean to say that 268 genuine large pointed implements, from gravel or any other geological deposit of Drift age, were then shown or even have been found in Yorkshire? I mean such old implements as we talk about when we speak of the Abbeville, St. Acheul, and Hoxne implements. I was not present at that meeting, and therefore did not sce the collection referred to, but I do not believe it contained ten-if, indeed, any such at all. And did not that number include arrowheads, flakes, and all sorts of things ?*

That there may be no mistake about the sort of flint implements we mean, we annex a woodeut $\left(\frac{1}{4}\right.$ nat. size) of the pointed kind, to which our remarks are restricted.

Mr. Tindall tells us he has three pointed tools with ground points : will he kindly transmit them to us for inspection, and will he tell us were not these found on the surface or in graves? If Mr. Tindall has three real fossil pointed implements, ground, he may pride himself on their uniqueness, and geologists on having got another evidence of the progress of the primitive men in their flint-chipping art, and a consequently additional proof of the primitiveness and antiquity of the unground implements; but they will be of no value to anybody unless the exact locality or conditions of the discovery is accurately narrated.

Mr. Tindall further states, that the deeper down in the Yorkshire beds the more primitive the weapons; and that there is a regular stratigraphical order of the advance of the workmanship. Will he tell us any one such section that will bear the inspection of ourselves, or Mr. Prestwich, Mr. Evans, or any other competent geologist. Will he furnish us with a list of the weapons found in Yorkshire by himself and others, and give the locality and stratigraphical and archæological conditions of each find? In this way, if right, he will do science the greatest service; if wrong, then the world will justify our scruples respecting the Yorkshire implements.

* In Mr. Wiltshire's paper it is stated that he exhibited 268 flint implements found by Mr. Mortimer and his children at Fimber. These were therefore historic and not fossil implements at all. - S. J. M. 
In these remarks we mean nothing whatever of personal reflection on Mr. Tindall, from whom, on all occasions when we have required it, we have received the greatest courtesy; but we think he is mistaken in respect to the nature both of the implements he has in his own large collection, as well as those he has seen in other collections.

Our opinion is that the mass of any real (i.e. not forged) flint-implements or weapons found in Yorkshire belong to a later or more immediately prehistoric period than that of the Drift gravels, and may come from graves or the débris of graves or be strewed on the soil. So far as I have seen, the Yorkshire large-pointed specimens are far smaller than even the smallest of the Abbeville and other true Drift examples, and it is highly desirable that the most reliable evidence be given to the world of their actual stratigraphical position. Mr. Tindall and other collectors and writers on this topic should remember, that where the practised eye has to judge of mere manipulatory results, the finest and most delicate differences may be of the greatest value. Let Mr. Tindall supply these facts. Let him give us the list of the Yorkshire implements and their localities, and give with each its position in the earth's strata, or state what other relics were found with it in the same grave, and then we shall have something tangible to work upon, and shall not spoil good paper in vague surmises and vain assertions. I have no preconceived views to advocate, I only want to get at the truth; and I do not mind what side I take, provided only that it really be the right side; but I do think the questions involved in these considerations so important that the evidence should be most searchingly investigated in every case before it be accepted; and it would be worse than culpable for the editor of the 'Geologist' knowingly to allow such a jumble of bistoric with fossil relics to pass unravelled. Science wants no man's assertion : she requires all the evidence on this topic to be well sub. stantiated, and to be supported by abundant testimony.-S. J. MACKIE.]

\section{GEOLOGICAL NOTES IN THE GREAT EXHIBITION.}

South Australia.- The main feature in this colony is the Mount Lofty Range, or Adelaide Hills, as they are indifferently called, which, about 30 miles in length from north to south, rise to an elevation of 2400 feet, and wooded to their summit. Between these hills and the sea are the great Adelaide Plains, so notable for their great crops of wheat and other corn. The chief topics, however, for our notice, are the mineral products. The chief source of mineral wealth in South Australia is copper. The Burra-Burra mine has long been famous, while the astonishing yield of some of the mines on Yorke's Peninsula brings them into perfect rivalry with it. Again, to the north of Spencer's Gulf mineral discoveries of the highest value have been made, and only the requisite facilities for transport-labour and capital-are required to develop them. It is in that district that the works of the Great Northern Mining Company are in operation.

The Burra-Burra mines-the vast productiveness of which is of worldwide celebrity-are about 90 miles N.E. from Adelaide, and the works were commenced, in $\mathbf{3 8 4 5}$, in the copper rock which projected from the surface, with ten miners, a smith, and a captain. They now yield employment directly to upwards of 1100 persons. Although the works were

VOL. $\mathbf{}$. 